\title{
Política exterior \\ de D. João VI \\ no Brasil
}

ANTÓNIO PEDRO VICENTE

\begin{abstract}
A unidade territorial e política da antiga colónia portuguesa da A América do Sul é normalmente aceite como uma consequência 1 do estabelecimento, por parte dos portugueses, de um governo colonial centralizado que viria a permitir uma herança de unidade. A administração espanhola, bem pelo contrário, teria criado as condiçōes para uma repartiçăo de estados no seu império colonial americano.
\end{abstract}

O estabelecimento de instituiçóes monárquicas no Brasil, a partir de 1808 , contribuiu estamos hoje certos e, aliás, alicerçados numa larga tradiçăo histórica, para uma mutaçăo pacífica do estado de colónia à situação de Estado Independente. A dinastia de Bragança ao transferirse para o Rio de Janeiro, ao transportar para a colónia todo o aparelho institucional do reino abandonado às intenções napoleónicas, deu um passo gigantesco, náo só garantindo a sua própria sobrevivência activa, institucional e política, como acentuando essa unidade administrativa e territorial no Brasil. A independência do Brasil, já vislumbrada mas ainda não almejada irá, a partir dessa data, caminhar com segurança e, mais ainda quando, alguns anos mais tarde, se consubstanciar o artifício político do reino no Brasil ou, melhor diríamos, Portugal e Brasil, um mesmo reino.

Muitos anos decorridos, após 1822, o Império do Brasil permanecia sob a égide dos Braganças. A antiga colónia diferenciava-se, politicamente, dos regimes vigentes na maior parte do continente americano, estruturando, assim, na unidade política a unidade do território. Uma situaçăo que tem algo de paradoxal deriva da circunstấncia de, através da continuidade da família reinante no exercício do poder, se objectivar "Simultaneamente, a continuidade e a separação, relegando os grupos dominantes da ex-colónia a uma posição de passividade no processo de independência e na formação da unidade territorial e político do Brasil" (1).

Muito naturalmente os variados grupos sociais existentes na colónia, potentes nos seus desígnios, alguns deles, com preponderância 
nos sectores regionais, actuaram politicamente numa contensão pragmática. Uns sujeitando-se ao poder governamental na perspectiva dos interesses nacionais e na salvaguarda das cobiças externas que, no passado, haviam tentado a ruptura. Outros, táo simplesmente, aceitando uma centralização que, na sua inserçăo no imenso território permitia, sem dano maior, a continuação do exercício, a nível regional, desses grupos sociais dominantes. Aliás, a tradição era descentralizadora e proporcional à extrema largueza do território. $O$ comando metropolitano sempre teve essa noção e afirma um largo historial onde os Regimentos de Tomé de Sousa, da primeira metade do século XVI ou o de Vidal Negreiros, um século depois, espraiando a sua administração em sectores territoriais permitiam, inclusivé, que núcleos populacionais fossem porta-vozes directos com o Rei. O regime de vice-rei ou de Capitanias Gerais, instituído na época pombalina, confinava a autoridade de cada um às suas dimensóes territoriais, no que diz respeito ao exercício do poder.

Governo central só existia em Lisboa. No Brasil consubstanciavase a imanaçáo de regras, códigos, ditames ou leis de origem portuguesa que, necessariamente, se centralizavam numa capital administrativa brasileira e, depois, se aplicavam de acordo com a especificidade e necessidade de cada parcela do imenso espaço colonial contribuindo, isso sim, na sua diversidade, para a unidade territorial que, com alguns resultados e oscilaçóes fronteiriças foi mantida até a época da directa governação dos Braganças. A imagem duma maior centralização governativa é, aliás, fortalecida quando, em 1815, se reconhece o Brasil como reino associado a Portugal.

Quando o Príncipe D. João chegou ao Brasil - único território do imenso império português que desde sempre havia sido colonizado - encontrou uma estrutura governativa montada e os seus alicerces com a solidez que, uma peculiar estrutura jurídico-administrativa, havia cimentado com proveito para as necessidades metropolitanas. Não pretendeu, como amplamente se provou, modificar toda a teia social e administrativa que, até aí, havia permitido a unidade territorial. Trazia, consigo, os interesses económicos do seu mais velho aliado, agora mais necessitado de mercados económicos, perante a derrocada na América do Norte mas, simultaneamente, mais altivo, arvorado que estava em defensor e protector da casa de Bragança, cobiçada e quase extinta por Napoleão. São esses ingleses que alardeando os créditos conquistados no auxílio então prestado à mudança da casa reinante para a colónia e ostentando os galóes da protecção da metrópole face às investidas francesas irão, por um lado, exigir privilégios mas apoiando, por outro, a 
instituição monárquica que perdurará para além da independência. Essa continuidade monárquica aquiascerá os grupos dominantes que, internamente, sustêm qualquer vontade de configuração separatista a nível territorial.

D. João e o seu séquito político e militar não iria interferir com os costumes duma sociedade onde os seus grupos dominantes mantinham o regime de escravatura e sustentavam o tráfego negreiro, como alimento da mão d'obra. Aí, também, os ingleses só a partir de 1830 exercem pressão suficiente para conter os interessados terra-tenentes. A presença da coroa portuguesa na direção cimeira dos negócios políticos e jurídicos da colónia constituiria, até, um factor de continuidade. Só a imposição do constitucionalismo em Portugal virá a constituir-se em ingrediente de separação (2).

Por esse tempo estavam, pois, praticamente estabelecidos os limites que configuravam o território que hoje constitui o Estado Brasileiro. Aceita-se a tese de que a participação nos últimos anos de condição colonial do Brasil, da coroa tutelar a centralizar esse vasto território, constituiu um factor de continuidade, que ultrapassou a acto independentista. Sabe-se, também, igualmente, que a transposiçăo do Atlântico por parte dos Braganças, não obedeceu, em 1807, a projectos amadurecidos mas, antes, a uma necessidade premente de salvaguardar a integridade de uma das mais antigas coroas reinantes da Europa. Náo poderá, pois, observar-se uma simples intençáo pré-concebida nas tomadas de posiçáo que, logo após a chegada do Príncipe Regente, foram exercidas no sentido de expandir a tutela política sobre regióes limítrofes do Brasil. Aceitam-se, no entanto, naturalmente, as querelas surgidas tendo em vista assegurar fronteiras mas não se prevê, desde logo, a sua transposição num sentido expansionista.

Aliás, uma breve alusão às motivaçóes directas que levaram a Corte para o Rio de Janeiro e um esboço, embora singelo, do Brasil que se deparou aos novos governantes deve ser lembrado. As circunstîncias criadas em Espanha pelo expansionismo francês, quase similares e paralelas às lusitanas, mas em que avulta o facto de a coroa de $S$. M. Católica ter claudicado nas mãos de Napoleáo, estabelecem, desde logo, um abissal contraste. Esse factor acrescentado à existência dè veleidades reinantes por parte da mulher de D. João, D. Carlota Jonquina, irá conduzir o governante português a uma política externa que, só remotamente, havia sido preconizada por algum político mais ousado.

Carlota Joaquina, a futura rainha de Portugal, ao induzir o seu marido a envolver-șe na política colonial espanhola da América, actuou 
de acordo com os seus próprios interesses, e valeu-se das circunstâncias provocados pela usurpação da coroa espanhola, por parte de Napoleão. Contou, igualmente, com o hipotético auxílio inglês, que julgava interessado nessa via, para garantir posiçóes comerciais que, n'outros locais do globo, agora lhe escasseavam. Carlota Joaquina chegou ao Brasil no momento em que a América espanhola se dividia em questóes internas estimulando, em muitos territórios, um clima de guerra civil. Se alguns defendiam a causa espanhola, muitos dos seus habitantes militavam, já, nos partidos independentistas. A Inglaterra, os EUA e a França vão situar-se na primeira linha de apoio à nova política. O Brasil vai colaborar, embora indirectamente, a partir de 1808. Ao chegar aí a Infanta espanhola pressente a dimensão desses movimentos nascentes, percebe até que ponto os ingleses apoiavam os rebeldes, toma conhecimento da política portuguesa do conde de Linhares ao pretender apoderar-se de parte dos domínios espanhóis, e entra num jogo perigoso, que oscilava entre a reuniāo das colónias espanholas e a queda desses domínios, em poder de Napoleão. Muitas alternativas foram, ao tempo, pesadas na balança dos acontecimentos, perante as desorientaçócs e oscilaçóes de muitos dirigentes dessas colónias. Alguns deduziam, para sua conveniência, a doutrina jurídica que vinculava a América à coroa e não à Naçáo Espanhola. Prisioneiro que estava o rei legítimo de Espanha, a soberania reverteria, naturalmente, aos povos os quais obtinham, assim, o direito à livre formação do seu próprio governo. Outras facçōes, mais moderadas, proclamavam a possibilidade de criaçăo de monarquias independentes onde reinassem príncipes de sangue Bourbónico. Alguns membros das classes dominantes da Argentina como Belgrano, Castelly y Saavedra viram, na circunstância, quanto lhes era útil a proximidade geográfica de Carlota Joaquina para a obtenção, em Buenos Aires, de uma monarquia constitucional. E no seio destas intrigas e no turbilhão de interesses do mais variado cariz, que o Príncipe Regente vai ter que desenvolver a sua acção e será com a sua própria mulher que, inicialmente, se verá obrigado a regular o processo da política externa que mais conveniente se ofereça aos interesses de colónia brasileira.

Já aludimos à situação portuguesa ao tempo da Revoluçãa Francesa. Um novo cenário se criou com grande influência no futuro histórico do Brasil. Reinava D. Maria I quando as repercussōes da Revolução Francesa começaram a determinar a política externa de Portugal e de outros países europeus. Em 1792, D. João, Príncipe do Brasil, passou a exercer as funções magestáticas em nome de sua mãe. Pouco depois registrava-se a reacção de Portugal para com a Convenção. $O$ representante do governo francês em Lisboa deixou o seu posto e acordou-se 
uma acção conjunta terrestre e naval, com a Espanha e França, além de outras medidas para proteger o comércio marítimo português.

As açōes militares de 1793-1795, nos Pirinéus, em que Portugal se juntou à Espanha contra a França, foram também determinadas no contexto político que se projecta em 1807 e determina a partida da Corte para o Brasil. Se, por um lado, o governo do Príncipe Regente entendia que a neutralidade era a melhor política, por muitas decisōes internacionais serem tomadas sem o conhecimento da coroa portuguesa, por outro lado, "o girar no turbilhāo das potências beligerantes" contribuía para actos sem uma definiçāo de posiçóes, e por consequência, abrindo perspectivas para um estado de luta armada. A paz entre Espanha e França deixava Portugal em situação difícil. Em 1797 negociou-se em Paris uma trégua, mas o acordo foi desautorizado pelo Príncipe Regente, que o considerou lesivo dos interesses portugueses no Brasil e, assim, se renovaram as hostilidades, prosseguindo a situação de guerra marítima.

O golpe de Estado de 18 Brumário, que entregou a Bonaparte a chefia política da França, anunciava um aparente período de paz que, em breve, virá a ser posto em causa. Fazem-se e desfazem-se as alianças na Europa. Em Setembro de 1799, Portugal assina um pacto de amizade com a Rússia, que mais deteriorou as relaçóes entre a Espanha e Portugal. Carlos IV de Espanha, apesar dos laços de sangue que o uniam à Corte portuguesa, não perdoava a forte ligação de Portugal com a Inglaterra. Em 20 de Maio de 1801 Portugal viu-se invadido por forças espanholas e francesas através da sua fronteira alentejana, numa acçáo que viria a ser conhecida como a Guerra das Laranjas. Em 29 de Setembro de 1801 assinou-se um tratado de paz bastante pesado parn os portugueses e que provocou a cessão da praça de Olivença a favor de Espanha e da Guiana, na América, em favor da França.

No início do século XIX o governo francês nomeou dois Embaixadores para Lisboa, cuja acção se traduziu na pretensão de afastar Portugal da tutela inglesa. Lannes e, depois, Junot, não esmoreciam nos seus intentos, criando a Portugal uma situação que acarretava pesadas obrigaçōes de ordem comercial. Quando da residência de Junot, em fins de 1805, a neutralidade mantinha-se em estado periclitante e a França continuava a receber as indemnizaçóes monetárias com que Portugal a tentava manter. As intimidaçóes de exigência de ruptura com a Inglaterra, por parte do Embaixador, consubstanciando-se no fecho de portos portugueses a navios ingleses, respondia o governo português com os mesmos e já antigos argumentos: "a monarquia portuguesa compóe-se 
de estados espalhados nas quatro partes do globo que ficariam inteiramente expostos, no caso de uma guerra com a Grã-Brctanha" (3).

Em Janeiro de 1806 já a Espanha fizera reunir um exército nas fronteiras de Estremadura e ameaçava o Alentejo, certa de que o seu vizinho não se poderia manter muito tempo no estado de neutralidade. O êxito de Napoleão nas campanhas do continente permitia-lhe recorrer a meios de força para obrigar a Inglaterra a fazer a paz com a França, sendo um deles o de fechar os portos portugueses a todos os navios ingleses. Se um pequeno adiamento ocorreu, em parte derivado da coligação contra a França e de mudanças de política na Itália, o rompimento era um facto esperado. Consumada a vitória de Iena contra os prussianos, decretou-se em Bailen, em Outubro de 1906, o estado de bloqueio às ilhas britânicas. Consumava-se, assim, o preâmbulo da invasão de Portugal como consequência natural dos triunfos franceses e como forma de aniquilar o poderio da Grä-Bretanha. O governo de Lisboa foi notificado das imposiçóes francesas a que devia sujeitar-se. A exigência cra natural, quer pela sua posiçāo geográfica, importante para a guerra naval, quer pelas ligaçóes económicas à Inglaterra.

O governo português, em Setembro de 1807, dava uma aparente adesão ao Bloqueio Continental. Um mês antes assinava-se o Tratado de Fontainebleau, que estipulava as condiçóes da invasăo de Portugal. Já em Baiona um exército francês se preparava, com a aquiescência de Espanha, para atravessar este reino em direcção à fronteira portuguesa. Saía-se de um estado de tensão para se entrar num estado de guerra. No período que precedeu a primeira invasáo francesa, o governo de Saint James respondia aos pedidos de auxílio vindos de Portugal e declarava que não permitia qualquer acto hostil contra os ingleses residentes em Portugal. Mas, evasivo no auxílio, "prometia e declarava, sem hesitação, ao Regente, o apoio naval suficiente para a transferência do governo de Lisboa para o Rio de Janeiro" (4).

A ocupação do território português ia, agora, consumar-se com a primeira das invasóes francesas e a posterior ocupação do país por duas outras invasōes, respectivamente, em 1808 e 1810 . O país ficaria mais empobrecido e nem a consolação das vitórias dos exércitos anglo-lusos lhe traria vantagens. Portugal iria viver, até à revolução liberal de 1820 , um clima de guerra com as naturais consequências. A ausência da $\mathrm{Fa}$ mília Real, a influência do Marechal Beresford na Regência a quem, aliás, se reconhecia o valioso auxílio prestado na expulsão dos franceses, mas que não deixava de ser um governante estrangeiro e, por fim, a Inglaterra procurando extrair as maiores vantagens de ordem política $\mathrm{e}$ comercial, da protecção militar que concedera ao seu velho aliado. 
O embarque da Família Real para o Rio de Janeiro, na véspera da entrada das primeiras tropas francesas, insere-se num pensamento que não era novo na história portuguesa. $O$ Brasil possuía todas as condições, não apenas para uma estável fixação, como para a construção de um verdadeiro império. Vinham de longe as idéias a este respeito. Em 1803 o conde de Linhares apresentara uma memória ao Regente, para a transformação da colónia num Estado imperial. Mas já em 1801, materializado o avassalamento napoleónico da Europa, o Marquês de Alorna afirmara numa exposição ao Príncipe: "Vossa Alteza Real tem um grande império no Brasil, e o mesmo inimigo que ataca agora com tanta vantagem talvez trema e mude de projecto, se V.A.R. o ameaçar de que se dispóe a ser imperador naquele vasto território adonde pode facilmente conquistar as colónias espanholas e aterrar em pouco tempo as de todas as potências da Europa" (5). Tais eram os projectos recentes em que se aludia às vantagens da Família Real residir no Brasil.

Era, pois, natural que, conhecidas as intençóes francesas, os mais prudentes estadistas portugueses avivassem os antigos projectos da mudança da Corte para o Rio de Janeiro. Se alguma hesitação ainda se fez sentir, os factos trataram de a demover quando, em 13 de Outubro de 1807, Napoleão afirmou em Fontainebleau que "a casa de Bragança cessara de reinar". E, mais ainda, ao chegar a notícia a Lisboa, em 23 de Novembro do mesmo ano, de que as tropas francesas de Junot haviam transposto a fronteira do Tejo.

No dia 29 fizeram-se os navios à vela para o Novo Mundo. Essa viagem viria a ter um extraordinário significado na história do Brasil. Pinto de Aguiar, no estudo $A$ abertura dos Portos do Brasil, vai ao ponto de afirmar que com essa atitude, e ainda, através de uma série de medidas de natureza económica que atendem a um processo já iniciado, se aglutinaram vários movimentos que, irrompendo no de Pernambuco $\mathrm{em}$ 1817 e em posteriores levantamentos, haveriam de escrever "as imorredouras páginas da independência política" do Brasil (6).

$\mathrm{Na}$ verdade, quando $\mathrm{cm} 8$ de Março de 1808 a Família Real chegou ao Rio de Janeiro, tinha inicio a última ctápe de um processo autonomista que culminou na independência política do Brasil. $O$ príncipe D. João era o testemunho vivo das transformaçōes que, vindas do último quartel do século XVIII, determinaram um longo período de renjuste, com alternativas de movimentos reformistas e rupturas revolucionárias. Coincidindo com a superação dos regimes absolutos em Portugal e Espanha, iriam ter lugar os movimentos de emancipaçáo do domínio colonial europeu. 
Como o seu vizinho espanhol, Portugal possuía um importante império colonial, onde o Brasil constituía a principal peça.

No entanto, as possessóes lusitanas, na sua organização interna e na sua política externa, apresentavam traços específicos. Ao contrário de Espanha, onde as Cortes, entre 1714 a 1789 , se haviam reunido quatro vezes, em Portugal jamais elas haviam sido convocadas desde 1698. A monarquia portuguesa embora esclarecida com Pombal, tornara-se mais absoluta que a espanhola. Apesar da existência de lojas maçónicas, marcantes desde os finais do século XVIII, Portugal era mais impenetrável que o seu vizinho a qualquer forma de propaganda revolucionária. No campo da política exterior, Portugal mantinha-se fiel, desde 1386, à aliança com a Inglaterra, com laços reforçados na Restauração (1661) e no Tratado de Methuen (1703). Com justeza afirma Jacques Godechot que os portugueses continuavam, agora, prontos a seguir "como uma chalupa a esteira do navio de linha britânica" (7).

Impōe-se examinar o Brasil que o príncipe D. João foi encontrar em 1808. De acordo com Bartolomé Bennassar, diremos que o Brasil teve um crescimento discreto que acompanhou o ritmo da ocupação territorial. Até finais do século XVII não viu o seu interior ocupado. A sua evolução demográfica mostrava-se díspar da das colónias espanholas. Até ao descobrimento de Minas Gerais era pouco populado e possuía um nível cultural que não the permitia uma rendosa exploração económica. Neste campo impóe-se considerar os ciclos anteriores da madeira, do açúcar e do ouro. Surgia, agora, o tempo das plantaçóes, que levou a um novo ciclo de agricultura diversificada: o tabaco, o algodão, o cacau e o gado passaram a representar importante papel na conjuntura económica brasileira até aos primeiros anos do século XIX.

Também as estruturas políticas do Brasil tinham características muito especiais que as diversificavam em relação às possessōes espanholas da América. Efectivamente, este imenso território raramente foi para os portugueses motivo de uma carreira política e administrativa. Nos primeiros séculos de ocupação, a política social partiu mais da Igreja Católica do que da coroa portuguesa. Assim, os jesuítas foram sobretudo os tutores dos desprotegidos, os combatentes das epidemias, os vigilantes dos costumes e os protectores dos índios que, muitas vezes, eram libertados da condição escrava e colocados em aldeamentos que eles próprios governavam.

A fixação da Família Real portuguesa no Brasil alterou, em certa medida, a situação deste território. De simples colónia passava à condição de sede da monarquia lusitana. Modificaçōes na organizaçáo ad- 
ministrativa tinham de se implantar, dada a transferência para o Rio de Janeiro do governo, das repartiçóes e dos tribunais vindos de Lisboa. As Secretarias de Estado funcionavam na nova capital, ali se estabelecendo os órgãos de administração pública e da justiça. Entre outros, o Conselho de Estado, as Mesas do Desembargo do Paço e da Consciência e Ordens, o Conselho Supremo Militar e o Conselho de Fazenda. O Tribunal de Relação do Rio de Janeiro foi elevado à condição de Casa da Suplicação a qual, como órgão superior da justiça, julgava em última instância. Muitas outras medidas administrativas foram tomadas no vicereino. Essa transformaçáo, estendida a todo o Brasil, através de reformas administrativas nas capitanias, da concessão de certo tipo de autonomia a grandes extensóes do território e do aumento da população, levaram - Brasil a uma nova situação. Preparava-se a proclamação, feita pelo príncipe em 1815, do Reino Unido de Portugal, do Brasil e dos Algarves.

No ano seguinte, por morte de D. Maria I, subia ao trono o Príncipe Regente com o nome de D. Joáo VI. Foi governante muito denegrido náo se oferecendo contudo, hoje dúvida, que marcou a nova era do Brasil. Deslocado de um país onde imperava o absolutismo, foi o único soberano europeu que se fixou no continente americano, sabendo adaptar-se às novas circunstâncias, criar as condiçóes para a existência de um novo Reino, evitar a fragmentação deste e preservar a sua dinastia.

Hélio Viana, ardente defensor deste Bragança, afirma que desde a publicaçáo do trabalho de Oliveira Lima, D. Joâo VI no Brasil, năo é mais possivel a inferiorização do papel que na sua transformação "coube ao Príncipe Regente e Rei, aqui residente, de 1808 a 1821. Suas qualidades pessoais de governante atilado e político adaptável às duras contingências que se lhe apresentaram não mais podem ser contestadas, à luz da documentação hoje conhecida" (8).

A situação criada com a fixação da Corte no Brasil traduzia-se numa ruptura política em Portugal, com consequências económicas num reino que ficara à mercê das invasões francesas. Geraram-se conflitos com o exacerbamento dos partidarismos consequentes da Revoluçăo Francesa. A emancipação do Brasil teve muito a ver com esses conflitos gerados numa metrópole assoberbada com dificuldades e em que as novas tendências liberais irão procurar modificar estruturas arcaicas.

Carlota Joaquina é figura geralmente controversa à qual os historiadores não criticaram somente a sua conduta política mas, penetraram, igualmente, na caracterização da sua vida privada classificada, geralmente, com traços marcadamente negativos. Por sun vez, o seu aspecto 
físico, foi transmitido para a posteridade por Savine, inspirado no terrível retrato devido à descrição da duquesa de Abrantes, mulher de Junot, Embaixador e, mais tarde, invasor e ocupante de Portugal. Discutida física e moralmente, julga-se, no entanto, que muito existe ainda por esclarecer tendo em vista um traçado mais justo da verdadeira imagem desta Infanta espanhola, que o destino associou à coroa portuguesa. Carlota Joaquina foi encontrar na América a Espanha da sua infância. Năo a que a viu nascer mas uma Espanha crioula onde poderia expandir sentimentos que, jamais, deixou de ligar a sua origem. Desde os 10 anos em Portugal qualquer observação biográfica, por mais ligeira que se ofereça, mostra uma Carlota Joaquina apegada às suas raizes, às quais apelava em qualquer circunstância, menos feliz, do seu quotidiano português. As suas ligações - estabelecidas após o desembarque no Brasil - aos nacionalistas argentinos, não deixam de mostrar até que ponto estes apreciaram os seus dotes governativos, abrindo mão da sua inesperada chegada à colónia e aproveitando o seu acrisolado amor ao país que a viu nascer.

Época riquíssima aquela $\mathrm{cm}$ que vai actuar. Estava-se em plena efervescência das novas idéias dando, corpo nessas colónias, à emancipaçăo para uma vida independente. Apelava-se profundamente à morte do antigo regime, atacado pelas revoluçốes que, na Europa e na América, estavam produzindo os seus frutos (9).

Pode, hoje, contrariar-se a idéia que se oferecia de Carlota Joaquina como possuidora de ambições desmesuradas e de enormes ânsias de poder e domínio. Antes deve ser observada como pessoa inteligente, culta, detentora, quiçá, de uma imaginação que a teria levado a projectos irrealizáveis. Quem a conheceu de perto, caso do Embaixador espanhol no Rio, em 1808 - o marquês da Casa Irujo -, considera-a pessoa dotada e capaz de dirigir um estado. $O$ conceito em que era tida $\mathrm{em}$ Espanha leva a que alguns dos seus partidários se dispusessem a aclamála como Regente de Espanha. Esse conceito é partilhado, mais tarde, entre alguns dos deputados das Cortes de Cadiz, na senda daqueles que nela haviam confiado anos antes. Mas os seus mais activos apoiantes serăo os espanhóis que, na América, queriam permanecer fiéis ao seu país, prevendo as revoluçóes, a que vieram a ser submetidos, no período $\mathrm{da}$ independência.

Aliás Carlota Joaquina, nas suas acçóes políticas, a partir de 1808, teve, contra si, os dirigentes políticos ligados ao Príncipe Regente como o conde de Linhares e o Embaixador inglês Strangford mas concitou, igualmente, apoios como o do Vice Almirante inglês Sidney Smith ou do General Goyeneche (10). Com o seu marido são conhecidas as dis- 
sensōes que sempre prevaleceram avolumadas a partir de 1806 , quando da sua suposta adesão a um movimento conducente ao seu afastamento. A conjura em que se viu imiscuída tinha o propósito de lhe conceder posição política na Regência do reino. $O$ afastamento conjugal, que só a conveniência das cerimónias solenes unia, foi um facto, a partir daí.

D. Rodrigo de Sousa Coutinho, o conde de Linhares, encarregado das secretarias da Guerra e Negócios Estrangeiros figurou, a partir de 1808, como o ministro mais influente do Brasil. Opositor do conde de Barca e, ao contrário deste, defensor do partido inglês, alcançou a sua áurea política com a chegada da coroa do Rio. Obediente ao Embaixador inglês e defensor da antiga aliança sem reticências, era um inimigo declarado de Espanha e, naturalmente, dos planos de Carlota Joaquina, em todos os negócios em que esta se mostrava sua defensora. D. Rodrigo, desejoso de adquirir vantagens derivadas da sublevaçăo das colónias espanholas, encetou uma política de anexação que o levou as tentativas, algumas delas objectivadas, de posse da banda oriental do Rio da Prata e da Colónia do Sacramento. Em relação a Buenos Aires estava sempre longe de secundar os interesses de Carlota Joaquina e do Embaixador espanhol. Paradoxalmente, contribuiu, sendo um típico ministro do regime absoluto, para o desenvolvimento de idéias revolucionárias e separatistas nas colónias espanholas convicto de vantagens para alimento dos seus desejos expansionistas e esquecendo, muitas vezes, o perigo que corria, na sua própria casa, com essa propagação.

O Embaixador inglês acreditado junto da Corte, no Rio de Janeiro, Strangford era, obviamente, o diplomata mais escutado e acatado. Zeloso dos créditos recentemente adquiridos, desenvolvia uma política de interesses económicos dirigida ao seu país aí englobando, não só o Brasil, onde adquirira as maiores vantagens, mas a vários territórios da América do Sul. Contrariando Linhares, evitava qualquer política de anexação em relação a territórios limítrofes. Embora, na metrópole espanhola, os ingleses fossem aliados e colaborantes na luta anti-napoliónica, na América do Sul, e no que dizia respeito às colónias desse país, apoiava os movimentos revolucionários e pro-independentistas. Efectivamente, era fácil para ele convencer alguns governantes coloniais de que, no caso de sair vencedora a França logo esse país exigiria o cabal reconhecimento dos mesmos a seu favor e, portanto, o caminho da independência era a melhor forma de se alhearem de tutelas afrancesadas. Strangford năo esquecera, com certeza, a política de Carlos III em relação a independência dos EUA, pensava na preponderância política que a Inglaterra exerceria sobre os futuros estados independentes e, claro, nos respectivos ganhos comerciais. Tudo era determinado, naturalmen- 
te, na hipótese de uma expansão francesa na América. Assim, e tendo em vista a consubstanciação dos seus planos políticos promoveu a sublevação de Buenos Aires, aconselhou o governo revoltoso, e acatou, na sua embaixada, os revolucionários políticos perseguidos, do Rio da Prata. Nesta linha de idéias combateu, naturalmente, todas as tentativas espanholas e portugueses contra as veleidades republicanas da Prata. Carlota Joaquina foi a sua maior vítima, enquanto acarinhava idéias protectoras dos que, embora renovadores, fortaleciam os laços com a coroa espanhola (11).

Aliás, uma política anti-espanhola neste sector não era de estranhar se, voltando a um passado recente, se observa o Tratado de Fontainebleau que postulava repartir o reino português entre a França e Espanha. Embora o decorrer dos acontecimentos, em breve, modificasse radicalmente a posição espanhola, em relaçăo aos interesses ingleses em 1808 , a ferida era ainda recente, como era recente o reatamento de relaçōes hispano-lusas. João, o Príncipe não esquecera, também, os acontecimentos de 1801, ano em que a Espanha de Godoy lhe invadira o Alentejo e o ocupara em poucos dias.

Em 1809 quando Carlos Martinez de Irujo - o Marquês da Casa Irujo - chegou ao Rio e se tornou sólido apoiante de Carlota Joaquina, já Stragford definira, com concisão, a sua política de relaçōes externas. Antigo diplomata espanhol nos Estados Unidos, com boa formação económica, era tido em elevada cotação. De nada valeu no entanto, ao futuro $1^{\circ}$ ministro de Fernando VII, o crédito adquirido quando se observam os resultados da sua acção no Brasil. Aliás, a sua situação tornou-se dúbia à medida em que, contrariar a Inglaterra na América do Sul, poderia equivaler a uma diminuição do auxílio que aquele país prestava à Espanha, no seu combate para a libertação do ocupante francês. Irujo assistiu, pois, quase passivamente, às manobras inglesas de ajuda à independência das colónias espanholas. Carlota Joaquina via, assim, os seus apoios claudicarem e as negociaçóes em que intervinha em favor da Espanha, ou para que fora chamada pelos patriotas argentinos, a carecerem de êxito.

Os portugueses e ingleses, considerando a Corte de Carlos IV submetida a Napoleão e, daí, as colónias espanholas sobre sua influência, sentiam o direito de aí expandir o seu domínio territorial. Também, ao Príncipe D. João, seriam constantemente recordadas as antigas quesílias que ensombravam as relaçōes com a Espanha, no que respeitava aos limites das terras brasileiras. Assim, no início da sua estadia no Rio e, ainda, pouco ciente do que, efectivamente, se passava em Espanha, o conde de Linhares, secundado pelos ingleses, iniciava uma política ve- 
lada de protefão sobre o Rio de Prata para, assim se afirmava, "evitar ... maiores males" (12). Foi a época do acordo perfeito entre o governo português e inglês. A própria Carlota Joaquina aí vislumbrava benefícios e, por isso, apoiou, de início, essa política.

A nota que o conde de Linhares dirigia ao Governo de Buenos Aires, em Março de 1808, propondo-lhe a protecçăo portuguesa e inglesa para evitar que, conquistado esse território por Napoleão, daí se produzissem ataques à colónia portuguesa, foi aceite como natural e teve a aquiescência de Carlota Joaquina na sua qualidade de única representante livre da dinastia bourbónica. Argumentava com a conveniência do seu pessoal reconhecimento, como representante de Espanha e do Príncipe Regente como protector dos seus direitos e prerrogativas. A resposta de Santiago Liniers foi, na altura, contrária a essa intenção protectora, alegando as recentes quesílias com a Inglaterra e a sua própria capacidade para repelir qualquer ataque francês. Esta primeira proposta, negada por Santiago Liniers e pelo cabildo de Buenos Aires, foi, obviamente, interpretada como uma tentativa de anexação pela parte portuguesa. Constituiu, também, como se sabe a única em que Carlota Joaquina colaborou com as autoridades portuguesas.

É a partir desta data que a Infanta espanhola vai lutar pelo reconhecimento dos seus eventuais direitos à sucessão da coroa de Espanha. Afastada dos interesses de anexação da Corte portuguesa, discordando da política inglesa de Strangford que jogava na independência, escolhia outra via de actuação, perante os sucessos que ocorriam em Espanha e consciente da situação do seu pai e do irmão, ambos privados de liberdade para dirigir a nação. Vai, entáo, lançar-se na nobre empresa de manter vivo o sentimento de fidelidade à metrópole. Assim se compreende a divulgação, em vários territórios da América do Sul, da sua conhecida Proclamação de 19 de Agosto de 1808 - Manifesto dirigido aos fiéis vassalos de S.M.C. o rei das Espanhas e Índias por sua Alteza Real D. Carlota Joaquina. Princesa de Portugal e Brasil. É o aparecimento de Carlota Joaquina como Infanta de Espanha e sua representante, esquecendo, ao personalizar a sua acção, os vínculos jurídicos e as obrigaçōes morais que lhe advinham da şua condição de consorte do Regente do Reino de Portugal. Configura, também, este Manifesto, toda a sua actuação futura, em relação às colónias espanholas. Esta proclamação e as que se seguiram foram aceitas por muitos espíritos, criando um movimento de simpatia pela causa da Infanta e ajudando, simultaneamente, a criação de um partido que vislumbrava colocá-la à cabeça do vice-reinado do Rio de Prata. No entanto, em Espanha, onde actuava uma Junta Central e Fernando VII, seu irmão, proclamara o seu juramento, 


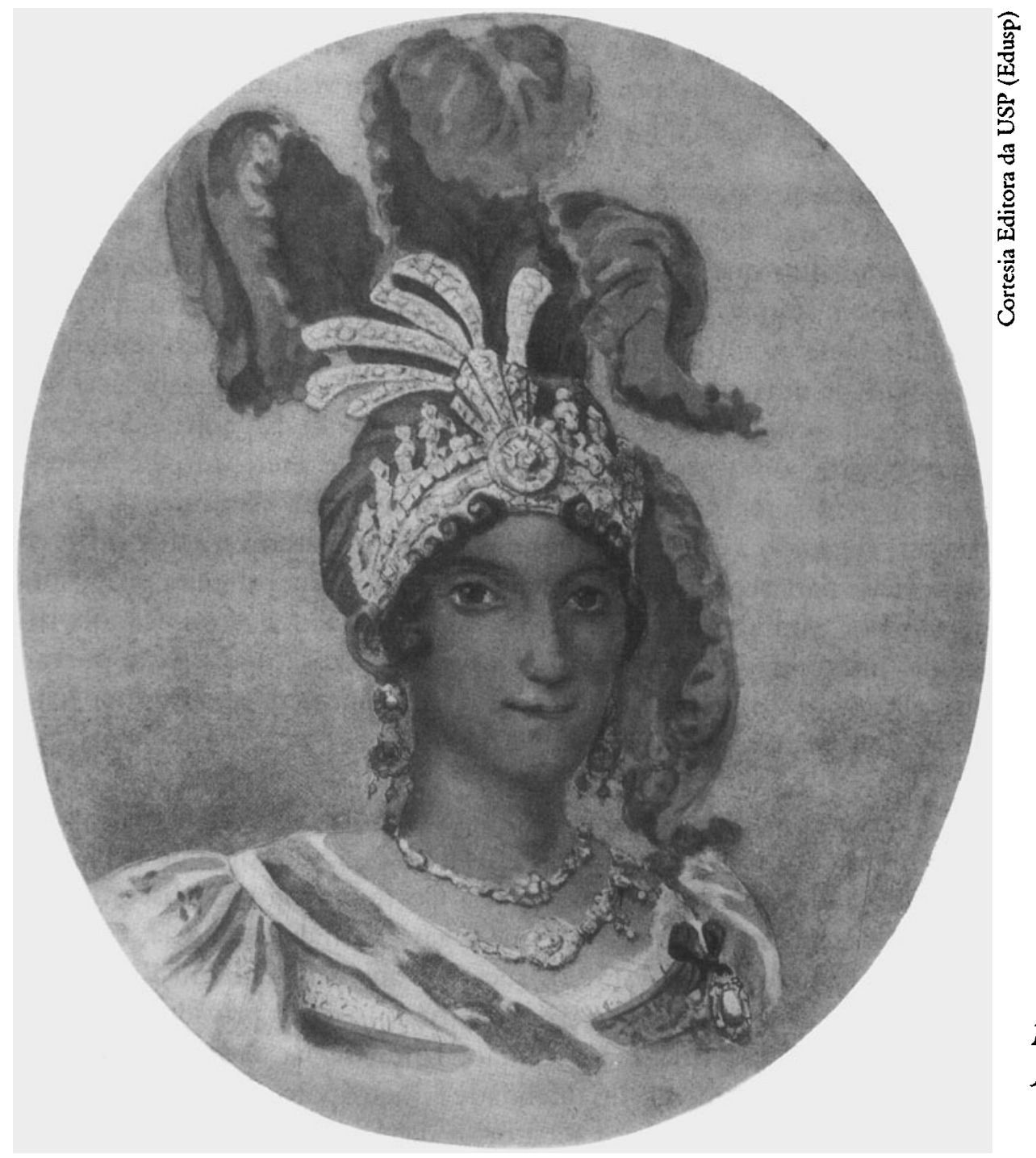

Rainba Carlota

Joaquina

a actuação de Carlota Joaquina foi julgada improcedente. Efectivamente, havia alegado direitos não previamente reconhecidos pelo governo espanhol. Só então, a Princesa, parece ter comprcendido que os seus actos careciam de uma base jurídica fundamental - a sua aceitação como sucessora, no trono de Espanha. Com esse fim irá, a partir de então, empreender os maiores esforços. Em Buenos Aires homens como Belgrano, Castelly e Passo a alimentarão, ainda por algum tempo, os seus desígnios: uma monarquia absoluta constituída na província do Rio de Prata, um governo próprio com a Regente à cabeça e um governo nacional, independente da metrópolc. A coroação de Carlota em Buenos 
Aires foi, também, idealizada. Para aqueles que já viam a Regente actuando e a convocar Cortes, esse governo devia transformar-se numa monarquia constitucional moderada e com as prerrogativas da coroa limitadas. Sabe-se, no entanto, que esse propósito jamais foi acalentado por Carlota Joaquina. Agentes no Rio e simpatizantes, em Buenos Aires, contribuíam entrctanto, para aumentar as expectativas dos seus partidários. Numa carta de 4 de Outubro de 1808, de Saturnino Rodriguez Peña, fala-se, com clareza, da coroação de Carlota Jonquina em Buenos Aires, alude-se às suas qualidades intelectuais, morais e políticas

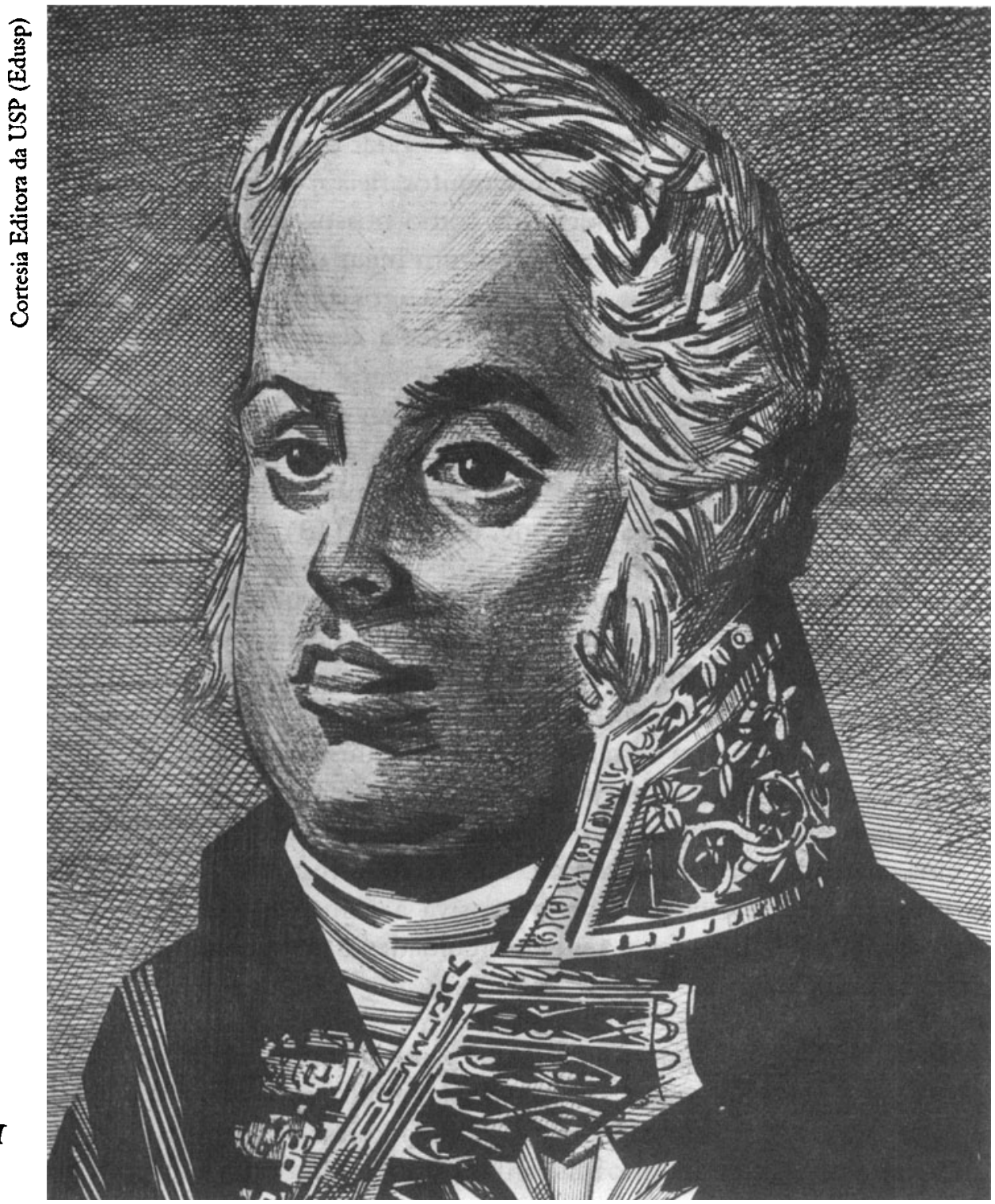


e insinua-se, à população daquela cidade, que demande a D. Carlota Joaquina a "sua proteç̧ăo e o imediato translado para aí ser proclamada como Regente" (13).

O pretexto para a sua viagem, até aí conservado em segredo surgiu, entretanto, a propósito de um dissídio entre o vice-rei de Buenos Aires, Liniers e o governador geral dessa cidade, Xavier Elio. Tinha como objectivo, essa deslocação que, a sua presença servisse para, "sossegar os ânimos e cortar toda a discórdia" (14). Necessário, no entanto se tornou o consentimento do Regente para que a viagem se objectivasse. A resposta do Príncipe D. Joáo merece transcrição completa pela clareza e objectividade com que alude às suas relaçōes com ingleses $\mathrm{e}$ espanhóis e pela ambiguidade em que patenteia relação ao respectivo consentimento.

"Ninguém melhor que V.A.R. pode estar certa que os sentimentos que me assistem em relação aos muitos fieis e leais espanhóis que actualmente devem ser considerados como nossos aliados. Na minha idéia foram sempre eles que ocuparam um lugar de preferência depois dos nossos amados vassalos e dos meus antigos aliados os ingleses. Eu ofereci-lhe a minha proteç̧ão e devem ter a certeza que sempre que recorrerem a mim serão alvo de uma particular benevolência. Por tudo isto acedo de bom grado ao seu pedido dando o meu real consentimento para que quando V.A.R. seja chamada de uma maneira formal e autêntica possa empreender a sua viagem em direcção aos territórios dos domínios de S. M. Católica. 22. nov. de 1808" (15).

Nessa missiva, invocava o Regente os seus sentimentos preferenciais em relação aos seus vizinhos espanhóis, os quais, para além, naturalmente, dos seus próprios vassalos e dos ingleses, eram dignos do seu afecto. Aproveitava D. João o ensejo para expressar a benevolente protecção que já tivera para com eles, numa clara alusão às acções que nesse sentido, empreendera, sem resultado, meses atrás. $O$ real consentimento para empreender a viagem não é negado mas subtilmente subordinado a uma chamada formal e auténtica. Náo transcurrera ainda uma semana o Príncipe Regente enviava nova missiva à Princesa. Agora era mais claro explicito e, desta feita, sem ambiguidades o pedido era-lhe, puro e simplesmente, negado:

" Princesa: não ignora a parte que tomo no que tanto deve interessar-la, seja pelos interesses de sua Real Família seja pelos dos meus amados filhos. Por este motivo năo pode admirar-se que lhe diga que sobre as suas relações com os Espanhóis do Rio de Prata, e da América Espanhola nada devo decidir, ou obrar sem ir de acordo com S.M.B. 
(Sua Majestade Britânica), e com o governo estabelecido em Espanha; e pode acreditar que em tempo oportuno nada the deixarei ignorar, para que possa tomar medidas sábias e prudentes, e que não comprometam a dignidade $\mathrm{e}$ interesses da minha Real Coroa. O seu plano de aparição no Rio de Prata para segurar aquelas províncias à Monarquia Espanhola, além de fazer sofrer o meu coraçáo pela idéia que necessariamente se une de separarnos algum tempo, tem também contra si, o que justamente lembra, e com toda prudência, e moderaçăo representa o Ministro do meu antigo e Fiel Aliado S.M.B., acreditado junto à muita Real Pessoa e por consequência é absolutamente inadmissível, nem por ora o estado daquelas províncias, exige uma resolução tão decidida e que pelo necessário aparato com que deveria tomar-se ofenderia os olhos da gente tímida e daria lugar aos discursos dos mal intencionados que procurariam envenenar a pureza das nossas intençōes e nos atribuiriam vistas, $\mathrm{e}$ planos ambiciosos bem alheios dos princípios que anima os nossos sensíveis coraçốes. Estes săo os sentimentos que estou certo servirāo de norma à sua conduta, e o Céu há-de abençoar resolução tão moderada, tão despida de toda a ambição, e não há-de esquecer-se nem de favorecer ainda a Real Casa de Bourbon, nem de proteger os direitos da Nossa Real Família. Esposo que muito a estima. Joāo. Rio de Janeiro em vinte e oito de Novembro de mil oitocentos e oito" (16).

Esta repentina mudança no ânimo do Príncipe Regente leva a considerar que, nesse pequeno intervalo o Ministro Linhares e o Embaixador de Inglaterra, entretanto informados dos desejos da Infanta, tivessem medido o alcance, as intençóes e as consequências de tal viagem.

Com esta negativa uma nova derrota contraria os intentos de Carlota Joaquina. O projecto ia ser abandonado, tanto mais que, em breve, muitos dos seus partidários expressam, com mais clareza, o desejo, de implantar uma monarquia constitucional, prólogo da futura independência. Sucede que esse tipo de governo e os anseios libertários que aí se advinhavam, năo se coadunavam com os sentimentos da Regente. Também, logo se verificou que, ao colocarem Carlota Joaquina ao seu serviço, muitos desses seus adeptos impunham, como condição indispensável, a sua renúncia e a de seus filhos, a todos os direitos sobre as coroas de Portugal e Espanha. Desejavam um monarca desligado de outras naçóes. Ora Carlota Joaquina aspirava a Coroa de Buenos Aires, fundando-se nos seus eventuais direitos à coroa de Espanha.

Aliás o projecto de uma monarquia governando no Rio de Prata, regida por um membro da Casa Real Espanhola tinha os seus antecedentes. Já o conde de Aranda e Manuel Godoy haviam proposto a Carlos 
III e Carlos IV, como "medida geral para todas as colónias espanholas", que no caso de uma separação há muito temida, se obrara, não com o cariz de um desmembramento, mas através de monarquins regidas por elementos da família Bourbon para que, assim, se mantivesse vivo o laço de uniāo com a mãe pátria (17).

Não deixa de ser curiosa a similitude e paralelismo que representa a atitude do filho desta princesa espanhola que, ao proclamar a independência do Brasil, aí continua os laços sanguíneos da velha tutela e conserva, no Império brasileiro, um sistema governativo de tipo monárquico que perdurará até quase ao século $\mathrm{XX}$.

Extinto o motivo de intervenção luso-brasileira com a organização de um governo legitimista em Espanha, fiel a D. Fernando VII, apareceu outro que justificou futuras acçóes bélicas ao Regente D. João este, de mais graves e prolongadas consequências.: Trata-se do que teve origem na criação independente das Províncias Unidas do Rio de Prata as quais, arvorando-se em naturais herdeiras do anterior vice-reino Espanhol com sede em Buenos Aires, intentaram justificar, assim, a anexação do Alto Peru, do Paraguai e do Bando Oriental. A reacção negativa das próprias populaçōes, nas duas primeiras regiôes, provocou intervençáo luso-brasileira, impossibilitando esta última: D. Joăo viu, aí, a necessidade de manter a fronteira conquistada na guerra de 1801, com a incorporação ao Brasil dos Sete Povos das Missóes Orientais do Uruguai, assim como a definitiva perda da Colónia do Sacramento. Tudo se justificava como represália à injustiça do tratado de Santo Ildefonso. Tinha-se, igualmente, em vista o regresso aos ideais de trocas e compensaçóes que haviam presidido ao tratado de 1750 , firmado em Madrid. D. João com prévio conhecimento e concordância do Embaixador espanhol, Marquês da Casa Irujo, actuou não para conquistar qualquer território pertencente a Fernando VII, mas antes forçado a garantir as fronteiras brasileiras. Nesse sentido, invadiu e ocupou a Banda Oriental "de modo a extinguir a causa daquelas perturbaçōes" (18). É nesse espirito que devem ser compreendidas as campanhas de 1811 . e $1816 / 1820$.

Entretanto, Carlota Joaquina, esperava que em Espanha fóssem garantidos os seus direitos ao trono, convicta, sempre do seu papel histórico para a manutenção das colónias espanholas, senão dependenteś, pelo menos ligados por laços de sangue à metrópole européia. Com ésse fim procurava com tenacidade mas, cada vez com menos resultados, alimentar o sonho que teve algumas possibilidades de concretizar, não fora o cariz revolucionário das acçōes conducentes a independência que, naturalmente, se iriam produzindo: 
Ao pretender elaborar-se um retrato de Carlota Jonquina, aludiuse, necessariamente, a um caminho por esta traçado que a poderia ter conduzido ao desempenho de um papel mais saliente no tablado histórico. No entanto, vários factores e de índolc diversa, apagaram os seus anseios. Por um lado, seu marido, o futuro rei D. João VI, raramente contribuiu para uma coincidência de objectivos. Por outro lado, a excepcional importância da Aliança inglesa, exacerbada pelos acontecimentos ocorridos na Península Ibérica, conduziu a um aproveitamento eficaz do qual, o representante da Grã-Bretanha, deu fecundo testemunho.

Também já se insinuou que o velho contencioso que a Inglaterra tinha para com a Espanha, a qual no turbilhăo da Revoluçăo Francesa, nem sempre optou, politicamente, pelos ditames da mais velha aliada de Portugal, viria a constituir argumento contrário aos interesses de Carlota Joaquina. Aliás, Strangford, nunca escondeu os objectivos de engrandecimento comercial do seu país. Aliado ao pensamento do seu chefe, o ministro Canning e actuando no seu papel de aparente neutralidade, não deixou, jamais, de apoiar os primeiros rebeldes que, nas colónias espanholas, davam sentido a esperanças independentistas.

Também o ministro Linhares, consclheiro cscutado do Regente, declaradamente anti-espanhol e fiel servidor da velha Albion, contrariou, necessariamente, os desígnios espanhóis da impetuosa Infanta.

Figura controversa na opiniño de contemporâneos e analistas que, através dos tempos, se lhe referiram, esta mulher de ânimo perspicaz e de elevados dotes de espírito para muitos, é considerada, para outros, ambiciosa tenaz, violenta e dominadora da vontade de um marido que, por ela, seria desdenhado e desprezado.

Contudo e curiosamente não é frequente, entre os seus biógrafos, a utilizaçăo de algum epiteto que a classifique como traidora aos interesses portugueses. Seria, efectivamente, classificaçăo injusta pois, no seu quotidiano português, durante quase meio século, que culminou com a sua morte, em 1830, quem estudou a sua acçáo, no campo político, poderá, tão somente, afirmar, com alguma justeza, que Carlota Joaquina, fracassada nos seus múltiplos propósitos, não deixou, jamais, de prosseguir projectos a que não faltaram certos méritos e que, a realizar-se, mudariam o curso dos acontecimentos. Pecou, sim, se isso é pecado, pelo tenaz, acrisolado e profundo patriotismo na defesa dos interesses espanhóis, parecendo esquecer o matrimónio, que celebrara, criança ainda, com o futuro rei de Portugal. Carlota Joaquina, e este é traço marcante do seu caracter, em momento algum se deixou embalar 
nas novas ideologias que, tanto no seu país natal como naquele que jamais adoptou, conduziram aos movimentos que estabeleceriam um estado constitucional e liberal.

\section{Notas}

1 Lia Osório Machado. Artifício político en el origen territorial do Brasil. In Horácio Capel (coord.), Los cspacios acotados. Geografia, dominación social, Barcelona, 1990, p. 214.

2 Idem, ibidcm, p. 218-219.

3 Eduardo Brazāo. História diplomática de Portugal, v. I 1640-1815. Lisboa, 1932, p. 239.

4 Durval Pires de Lima. Os franceses no Porto, 1807-1808. Porto, 1949, p. 295.

5 Luis Norton. A Corte de Portugal no Brasil. São Paulo, 1938, p. 15-16.

6 Pinto de Aguiar. A abertura dos Portos do Brasil. Salvador, 1960, p. 36.

7 Jacques Godechot. Europa e Amcrica no tcmpo de Napolcáo, (1800/1815). São Paulo, 1984, p. 122.

8 Helio Viana. Historia do Brasil. São Paulo, 1975, p. 368.

9 Antonio Ballasteros Beretta. Prólogo a Julián Maria Rúbio. La Infanta Carlota Joaquina y la política de Espanlsa en Amcrica $(1808,1812)$. Madrid, 1920 , p. X-XI.

10 Oliveira Lima. Fornzación listórica de la nacionalidad brasileña. Madrid, 1918, p. 168.

11 Julián Maria Rubio. Op. cit., p. 28/29.

12 Idem, ibidcm, p. 37.

13 Saturnino Rodrigues Peña estava exilado no Rio pois fora expulso de Buenos Aires por Liniers, devido à sua adesão aos interesses ingleses.

14 Archivo Historico Nacional. Madrid (A.H.N.M.) Estado Legajo 5837, 8.XI.1808.

15 A.H.N.M., Estado Legajo 5837, Carta do Regente para Carlota Joaquina de 22.XI.1808.

16 Idcm ibidcm.

17 Julián Maria Rubio. Op. cit., p. 63.

18 Helio Viana. Op. cit., p. 383. 


\section{Referências bibliograficas}

ARCHIVO Historico Nacional. Madrid (A.H.N.M.) Estado Legajo 5837, 8.XI.1808.

BERETTA, Antonio Ballasteros. Prólogo a Julián Maria Rúbio. La Infanta Carlota Joaquina y la política de Espanba en América (1808, 1812). Madrid, 1920.

BRAZĀO, Eduardo. História diplomática de Portugal, v. I 1640-1815. Lisboa, 1932.

GODECHOT, Jacques. Eutropa e Ambrica no tempo de Napoleấ, (1800/1815). São Paulo, 1984.

LIMA, Durval Pires de. Os franceses no Porto, 1807-1808. Porto, 1949.

MACHADO, Lia Osório. Artifício político en el origen territorial do Brasil. In Horácio Capel (coord.), Los espacios acotados. Geografia, dominación social, Barcelona, 1990.

NORTON, Luis. A Corte de Portugal no Brasil. São Paulo, 1938.

OLIVEIRA LIMA. Formación bistbrica de la nacionalidad brasilcfia. Madrid, 1918.

PINTO DE AGUIAR. A abcrtura dos Portos do Brasil. Salvador, 1960.

VIANA, Helio. Historia do Brasil. São Paulo, 1975.

\section{Resumo}

A unidade territorial e política do Brasil ao tempo da Independência nāo deriva de circunstâncias ocasionais mas de uma política ancestral que colocou a colónia em situaçăo bem diferente à dos territórios americanos sob tutela espanhola. A chegada ao Brasil de D. Joăo deu, no entanto, ainda maiores vantagens de natureza económica à Inglaterra. D. João nāo estabeleceu no Brasil uma política de expansāo territorial, não descurando, no entanto a consolidaçāo de fronteiras movediças, algumas ao sabor dos movimentos independentistas da época. D. Carlota Joaquina, rainha de Portugal, espanhola de nascimento, pretende envolver o seu marido na política colonial espanhola, actuando no seu próprio interesse e valendo-se das circunstâncias provocadas pela usurpaçăo da coroa espanhola, por parte de Napoleāo. A sua coroaçāo em Buenos Aires chegou a ser idealizada. Projectos de expansão falhados contudo, tanto mais que Carlota Joaquina jamais se deixou embalar nas novas ideologias tão caras aos independentistas das colónias espanholas e, simultaneamente, não tendo o apoio do marido e dos anglófilos ao serviço da coroa.

\section{Abstract}

The territorial and political unity of Brasil at the time of independence did not derive from circumstances but from a long-lasting policy that made for a very 
different situation than that of the territories under Spanish rule. However, the arrival of Prince D. Joāo in Brasil gave England even more economic advantages. D. Joāo did not develop a policy of territorial expansion in Brasil, but he did take care to consolidate frontiers, part of which were somewhat moveable, because of the pro-independence groups of the time. D. Carlota Joaquina, Queen of Portugal; Spanish by birth, attempted to envolve her husband in Spanish colonial policy, acting in her own interest and taking advantage of circumstances caused by Napolean's occupation of the Spanish crown. Her coronation in Buenos Aires was even idealized. However, these were unsuccessful expansionist projects, and moreover Carlota Joaquina was never an adept of the new liberal ideologies that were so clear to the pro-independence movements of the Spanish colonies. Neither her husband or the pro-English at the service of the Portuguese crown supported her.

Respeitada a ortografia do autor.

António Pedro Vicente, historiador, é professor da Faculdade de Ciências Sociais e Humanas da Universidade Nova de Lisboa.

Este texto foi apresentado à Cátedra Jaime Cortesão, implantada no IEA, em abril de 1992, através de convênio firmado entre a USP e a Comissão Nacional Para as Comemoraçóes dos Descobrimentos Portugueses (CNPCDP). 